\title{
CAN FIRMS WITH THE BEST TRAINING PROGRAM WITHSTAND THE STORM OF ECONOMIC POLICY UNCERTAINTY?
}

\author{
Vichet SUM \\ Department of Business, Management and Accounting, School of Business and Technology, \\ University of Maryland Eastern Shore, Kiah Hall 2117-A, Princess Anne, USA \\ E-mail:vsum@umes.edu
}

Received 27 September 2012; accepted 17 December 2012

\begin{abstract}
This study examines if firms whose training programs ranked as the best ones in the United States can withstand the changes in economic policy uncertainty. The regression analysis of monthly changes in economic policy uncertainty index, monthly returns on the CRSP value-weighted index, and monthly returns on an equal-weighted portfolio of public firms in the United States ranked consecutively from 2006 to 2011 in the top 50 of the Training Top 125 shows that the increased changes in economic policy uncertainty negatively affect the portfolio returns; however, this effect is not statistically significant at the $1 \%$ level. The result from regressing monthly returns on CRSP value-weighted index on the monthly changes of economic policy index yields a statistically significant negative coefficient at the $1 \%$ level, and this coefficient is more negative than the coefficient obtained from regressing the monthly portfolio returns on the monthly changes in economic policy uncertainty. This study provides empirical evidence of the ability of firms in the US with the best training program to withstand the storm of economic policy uncertainty better than the whole market. In other words, the findings suggest that firms with the best training program are more prepared than the whole market in responding to the changes in economic policy uncertainty.
\end{abstract}

Keywords: policy uncertainty, equity return, training, regression analysis, economic policy, market.

JEL Classification: E60, G12, G14.

\section{Introduction}

In the knowledge-based economy, sustainable success of the firms is determined by the quality of their employees who are valuable, rare, imperfectly imitable and unsubstitutable (Barney, Wright 1998; Gorman et al. 2004; Lopez-Cabrales et al. 2006; Shee, Pathak 2005; Wright et al. 1994). In addition to other company-related activities and programs, firms can ensure that they have access to the best talent by aggressively pursuing the best candidates through competitive recruitment strategies and by offering cutting edge training to their employees. An extensive host of research in strategic human resource management empirically documents the positive impact of training on 
the firm's performance and competitiveness (Akhtar et al. 2008; Barney, Wright 1998; Bartel 1994; Cutcher-Gershenfeld 1991; Gerhart, Milkovich 1990; Huselid 1995; Huselid, Becker 1996; Ichiniowski et al. 1997; MacDuffie 1995; Sum 2009, 2010, 2011). As a result, firms that provide quality training to their employees should be able to enjoy superior benefits and outcomes, on average, in the industry. For example, Sum (2012a) draws on evidence from the capital market and shows that a portfolio of public firms with the best training program generates positive risk premiums which are positive and economically greater than the mark risk premiums for the 5-year holding period intervals. A similar study conducted by Sum (2014a) shows that an equal-weighted portfolio of public companies with the best training programs earn positive risk-adjusted excess returns (some are statistically significant) from the single-index and four-factor models for the 3-year and 5-year holding period intervals. Other core benefits from quality training include quick response to market threats and opportunities, efficiency, productivity, differentiation, and innovation (Sum 2011).

\section{Background}

Many researchers have investigated how various macro variables in the real economy help explain the behaviors of returns and prices in the asset markets (Cochrane 1991; Cooper, Priestley 2005; Lamont 2000; Lettau, Ludvigson 2001; Piazzesi 2005). A stream of research has studied the effect of uncertainty related to the overall economy on the performance of capital markets. Sum (2012b, 2014b) reports the negative relationship between stock market performance and the change in the economic policy uncertainty in the United States and Europe; similar findings are documented by Dzielinski (2011) and Bansal et al. (2005). Ozoguz (2009) studies the relationship between uncertainty among investors and stock prices and finds a negative relationship among these two variables. Pastor and Veronesi (2011) argue that stock prices should fall in response to the increase in government policy uncertainty.

This paper argues that if, as a result of training, firms are able to recognize and quickly respond to market threats and opportunities, then firms with best training program should be more prepared than the market in responding to the changes in economic policy uncertainty. Therefore, this study is set up to test this argument by drawing on evidence from the capital market. Specifically, if this argument is valid and sound, then the changes in economic policy uncertainty that negatively affect stock market returns in a statistically significant manner should not affect returns on a portfolio of firms with the best training program in the same manner as the stock market returns. The problem of the current is to test if firms whose training programs ranked as the best ones in the United States can withstand the changes in economic policy uncertainty. This study is necessary because no prior study examines the impact of training in this fashion before, and it contributes to the further understanding of the impact of training. In addition to adding vital information to the strategic human resource management literature, this study also offers useful implication for investment and risk management in the stock markets. 


\section{Method and data}

First of all, this study constructs an equal-weighted portfolio of publicly traded companies in the United States ranked consecutively from 2006:1 to 2011:12 in the top 50 of the Training Top 125 published in the Training Magazine. Table 1 provides information about these companies. The monthly return data of each stock and CRSP value-weighted index are obtained from CRSP database. Monthly changes of economic policy uncertainty index in United States spanning from 2006:1 - 2011:12 are obtained from Economic Policy Uncertainty Index website located at http://www.policyuncertainty.com; the development of this index is performed by Baker et al. (2012). Three major components are included in the index construction; they are (1) "newspaper coverage of policy-related economic uncertainty", (2) "the number of federal tax code provisions set to expire in future years", and (3) "disagreement among economic forecasters as a proxy for uncertainty". Detailed methodology of this index is available at http://www.policyuncertainty.com/methodology.html.

\section{Hypotheses}

For the empirical set up, this study argues that if, as a result of training, firms are able to recognize and quickly respond to market threats and opportunities, then firms with best training program should be more prepared than the market in responding to the changes in economic policy uncertainty. If this argument is valid and sound, then the changes in economic policy uncertainty that negatively affect stock market returns in a statistically significant manner should not affect returns on a portfolio of firms with the best training program in the same manner as the stock market returns. The following hypotheses are to be tested:

- Null Hypothesis 1: Changes in economic policy uncertainty have no effect on the overall U.S. stock market.

- Alternative Hypothesis 1: Changes in economic policy uncertainty have a negative effect the U.S. overall stock market.

- Null Hypothesis 2: Changes in economic policy uncertainty have no effect on the equal-weighted portfolio of firms whose training programs ranked as the best ones in the U.S.

- Alternative Hypothesis 2: Changes in economic policy uncertainty have a negative effect on the equal-weighted portfolio of firms whose training programs ranked as the best ones in the U.S.

To empirically test the above hypotheses, the monthly returns on the CRSP value-weighted index are regressed on the monthly changes in economic policy uncertainty using an OLS regression as mathematically expressed in equation 1 . The expected regression coefficient is $\beta_{m}$ negative and statistically significant. Likewise, the monthly returns on the equal-weighted portfolio are regressed on monthly changes in economic policy uncertainty using an OLS regression shown in equation 2. The regression coefficient $\beta_{p}$ 
Table 1. Firms with the best training program from 2006-2011

\begin{tabular}{lcl}
\hline Name of the companies & Ticker & \multicolumn{1}{c}{ Industry } \\
\hline Aetna & AET & Insurance (accident and health) \\
\hline BB\&T & BBT & Regional banks \\
\hline Cerner & CERN & Software and programming \\
\hline EMC & EMC & Computer storage devices \\
\hline Microsoft & MSFT & Software and programming \\
\hline Paychex & PAYX & Business services \\
\hline Verizon & VZ & Communications services \\
\hline
\end{tabular}

obtained from the second regression is then compared to $\beta_{p}$. If the argument in this study is valid and sound, then one of the following conditions must be met:

1. $\beta_{p} \geq 0 \geq \beta_{m}$ ( $\beta_{m}$ and $\beta_{p}$ must be statistically significant at the $1 \%$ or $5 \%$ level);

2. $0 \geq \beta_{p}>\beta_{m}\left(\beta_{m}\right.$ must be statistically significant at the $1 \%$ or $5 \%$ level, and $\beta_{p}$ can be statistically significant or insignificant at the $1 \%$ or $5 \%$ level); or

3. $\beta_{p}=\beta_{m}\left(\beta_{m}\right.$ must be statistically significant at the $1 \%$ or $5 \%$ level, and $\beta_{p}$ must be statistically insignificant at the $1 \%$ or $5 \%$ level):

$$
\begin{gathered}
M R_{t}=\alpha+\beta_{m} \Delta E P U_{t}+\varepsilon_{t}, \\
P R_{t}=\alpha+\beta_{p} \Delta E P U_{t}+\varepsilon_{t},
\end{gathered}
$$

where:

$M R_{t}=$ return on the CRSP value-weighted index in month $t$;

$P R_{t}=$ return on the equal-weighted portfolio in month $t$;

$\triangle E P U_{t}=$ change in the index of economic policy uncertainty in the United States by taking the first difference; that is the value of economic policy uncertainty index in month $t$ less month $t-1$.

\section{Results}

Various descriptive statistics are reported in Tables 1, 2, and 3. The regression results reported in Table 4 show a statistically significant negative coefficients $\left(\beta_{m}=-0.0729013\right.$, $t=-2.46$ ) obtained from regressing returns on the CRSP value weighted index on the changes of economic policy uncertainty. This indicates that the changes in economic policy uncertainty negatively affect the stock market returns; this effect is statistically significant at the $1 \%$ level. As shown in Table 5, the coefficient obtained from regressing the returns on the equal-weighted portfolio of firms with the best training program on the changes in economic policy uncertainty is negative $\left(\beta_{p}=-0.0498, t=-1.60\right)$, but this coefficient is not statistically significant at the $1 \%$ or $5 \%$ level and it is greater than 
Table 2. Descriptive statistics

\begin{tabular}{lccc}
\hline Variables & Mean & Standard deviation & \# of Obs \\
\hline CRSP value-weighted index & 0.3714194 & 5.303564 & 72 \\
\hline Equal-weight portfolio & 0.7854764 & 5.449042 & 72 \\
\hline $\begin{array}{l}\text { Changes in economic policy } \\
\text { uncertainty index }(\triangle E P U)\end{array}$ & 1.678852 & 20.5141 & 72 \\
\hline
\end{tabular}

Table 3. Correlations

\begin{tabular}{cccc}
\hline & $\Delta \mathrm{EPU}$ & $\begin{array}{c}\text { CRSP value-weighted } \\
\text { index }\end{array}$ & $\begin{array}{c}\text { Equal-weight } \\
\text { portfolio }\end{array}$ \\
\hline$\Delta E P U$ & 1.0000 & & \\
\hline CRSP value-weighted index & -0.1876 & 1.0000 & 1.0000 \\
\hline Equal-weight portfolio & -0.2820 & 0.8665 & \\
\hline
\end{tabular}

Table 4. Regression results obtained from Equation (1)

\begin{tabular}{lcccc}
\hline & Coefficient & Std. err. & $t$ & Sig. \\
\hline Constant & 0.4938099 & 0.6059828 & 0.81 & 0.418 \\
\hline$\triangle E P U_{t}$ & -0.0729013 & 0.0296466 & -2.46 & 0.016 \\
\hline R-Square & 0.0795 & & & \\
\hline Adj. R-Square & 0.0664 & & & \\
\hline $\mathrm{F}(1,70)$ & 6.05 & & 0.016 \\
\hline
\end{tabular}

Notes: Number of observation $=72$; Durbin-Watson d-statistic $(2,72)=$ 1.783473 .

Table 5. Regression results obtained from Equation (2)

\begin{tabular}{lcccc}
\hline & Coefficient & Std. err. & $t$ & Sig. \\
\hline Constant & 0.869131 & 0.6374188 & 1.36 & 0.177 \\
\hline$\triangle E P U_{t}$ & -0.0498285 & 0.0296466 & -1.60 & 0.115 \\
\hline R-Square & 0.0352 & & & \\
\hline Adj. R-Square & 0.0214 & & & \\
\hline $\mathrm{F}(1,70)$ & 2.55 & & 0.115 \\
\hline
\end{tabular}

Notes: Number of observation $=72$; Durbin-Watson d-statistic $(2,72)=$ 1.904103 . 
$\beta_{m}$. The results satisfy the condition that supports the argument in this study that firms with best training program should be more prepared than the market in responding to the changes in economic policy uncertainty; that is: $0 \geq \beta_{p}=-0.0498>\beta_{m}=-0.0729013 ; \beta_{m}$ is statistically significant at the $1 \%$ or $5 \%$ level, and $\beta_{p}$ is not statistically significant at the $1 \%$ or $5 \%$ level. The results provide evidence from the capital market that firms with best training program in place are more prepared than the overall market in responding to the changes in economic policy uncertainty.

\section{Conclusions}

Based on an extensive stream of research in strategic human resource management which theoretically and empirically documents the impact of training on the firm's performance and competitiveness, this paper argues that if, as a result of training, firms are able to recognize and quickly respond to market threats and opportunities, then firms with best training program should be more prepared than the market in responding to the changes in economic policy uncertainty. The regression analysis of monthly changes in economic policy uncertainty index, monthly returns on the CRSP value-weighted index, and monthly returns on an equal-weighted portfolio of public firms in the United States ranked consecutively from 2006 to 2011 in the top 50 of the Training Top 125 shows that the increased changes in economic policy uncertainty negatively affect the portfolio returns; however, this effect is not statistically significant at the $1 \%$ level. The result from regressing monthly returns on CRSP value-weighted index on the monthly changes of economic policy index yields a statistically significant negative coefficient at the $1 \%$ level, and this coefficient is more negative than the coefficient obtained from regressing the monthly portfolio returns on the monthly changes in economic policy uncertainty.

This study provides empirical evidence of the ability of firms in the US with the best training program to withstand the storm of economic policy uncertainty better than the whole market. In other words, the findings suggest that firms with the best training program are more prepared than the whole market in responding to the changes in economic policy uncertainty. The implication for equity investment and risk management is that during the periods of high economic policy uncertainty in the US, investors can be protected from the exposure of the increased changes in economic policy uncertainty by holding a portfolio of firms with the best training program rather than the market portfolio. This study also offers useful implication for investment and risk management in the stock markets. For instance, during times with high economic policy uncertainty, investors may consider investing in publicly traded companies whose training programs ranked as the best ones because firms with the best training program are more prepared than the whole market in responding to the changes in economic policy uncertainty.

\section{References}

Akhtar, S.; Ding, D. Z.; Ge, L. G. 2008. Strategic HRM practices and their impact on company performance in Chinese enterprises, Human Resource Management 47(1): 15-32.

http://dx.doi.org/10.1002/hrm.20195 
Baker, S. R.; Bloom, N.; Davis, S. 2012. Measuring economic policy uncertainty. Mimeo: Stanford University.

Bansal, R.; Khatchatrian, V.; Yaron, A. 2005. Interpretable asset markets?, European Economic Review 49: 531-560. http://dx.doi.org/10.1016/j.euroecorev.2004.09.002

Barney, J.; Wright, P. M. 1998. On becoming a strategic partner: the role of human resources in gaining competitive advantage, Human Resource Management 37(1): 31-47.

http://dx.doi.org/10.1002/(SICI)1099-050X(199821)37:1<31::AID-HRM4>3.0.CO;2-W

Bartel, A. P. 1994. Productivity gains from the implementation of employee training programs, Industrial Relations 33(4): 411-425. http://dx.doi.org/10.1111/j.1468-232X.1994.tb00349.x

Cochrane, J. 1991. Production-based asset pricing and the link between stock returns and economic fluctuations, Journal of Finance 46: 207-234.

http://dx.doi.org/10.1111/j.1540-6261.1991.tb03750.x

Cooper, I.; Priestley, R. 2005. Stock return predictability in a production economy, in Proceedings of the 2005 American Finance Association conference, 21 August, 2005, Boston, MA.

Cutcher-Gershenfeld, J. C. 1991. The impact on economic performance of a transformation in workplace relations, Industrial and Labor Relations Review 44(2): 241-260.

http://dx.doi.org/10.2307/2524806

Dzielinski, M. 2011. Measuring economic uncertainty and its impact on the stock market, $\mathrm{Fi}$ nance Research Letters 9(3): 167-175. http://dx.doi.org/10.1016/j.frl.2011.10.003

Gerhart, B.; Milkovich, G. T. 1990. Organizational differences in managerial compensation and firm performance, Academy of Management Journal 33(4): 663-691.

http://dx.doi.org/10.2307/256286

Gorman, P.; Nelson, T.; Glassman, A. 2004. The millennial generation: a strategy opportunity, Organizational Analysis 12(3): 255-270.

Huselid, M. 1995. The impact of human resource management practices on turnover, productivity, and corporate financial performance, Academy of Management Journal 38(3) 635-672.

http://dx.doi.org/10.2307/256741

Huselid, M.; Becker, B. E 1996. Methodological issues in cross-sectional and panel estimates of the HR-firm performance link, Industrial Relations 35(3): 400-422.

http://dx.doi.org/10.1111/j.1468-232X.1996.tb00413.x

Ichiniowski, Shaw, K.; Prennushi, G. 1997. The effects of human resource management practices on productivity: a study of steel finishing lines, American Economic Review 87(3): 291-313.

Lamont, O. 2000. Investment plans and stock returns, Journal of Finance 55: 2719-2745.

http://dx.doi.org/10.1111/0022-1082.00304

Lettau, M.; Ludvigson, S. 2001. Consumption, aggregate wealth, and expected stock returns, Journal of Finance 56: 815-49. http://dx.doi.org/10.1111/0022-1082.00347

Lopez-Cabrales, A.; Valle, R.; Herrero, I. 2006. The contribution of core employees to organizational capabilities and efficiency, Human Resource Management 45(1): 81-109.

http://dx.doi.org/10.1002/hrm.20094

MacDuffie, J. 1995. Human resource bundles and manufacturing performance: flexible production systems in the world auto industry, Industrial and Labor Relations Review 48(2): 197-221. http://dx.doi.org/10.2307/2524483

Ozoguz, A. 2009. Good times or bad times? Investors' uncertainty and stock returns, Review of Financial Studies 22(11): 4377-4422. http://dx.doi.org/10.1093/rfs/hhn097

Pastor, L.; Veronesi, P. 2011. Uncertainty about government policy and stock prices, Journal of Finance 67(4): 1219-1264. http://dx.doi.org/10.1111/j.1540-6261.2012.01746.x 
Piazzesi, M. 2005. Bond yields and the Federal Reserve, Journal of Political Economy 113: 311-344. http://dx.doi.org/10.1086/427466

Shee, H. K.; Pathak, R. D. 2005. Managing people and technology for enhancing competitiveness: software industry perspective, Journal of Transnational Management 11(1): 65-82.

Sum, V. 2009. Strategic integration of training and innovation: significantly connected, Journal of Global Information Technology 7(2): 7-20.

Sum, V. 2010. The role of training and firm's competitiveness in the knowledge-based economy, Review of Business and Technology Research 3(1): 115-125.

Sum, V. 2011. Integrating training in business strategies means greater impact of training on the firm's competitiveness, Research in Business and Economics Journal 4: 1-19.

Sum, V. 2012a. Stock performance and the firm's training program, International Research Journal of Applied Finance 3(5): 554-559.

Sum, V. 2012b. Economic policy uncertainty and stock market performance: evidence from the European Union, Croatia, Norway, Russia, Switzerland, Turkey and Ukraine, Journal of Money, Investment and Banking 25: 99-104.

Sum, V. 2014a. Quality of the firm's training and stock returns, Journal of Wealth Management 16(4): 48-54. http://dx.doi.org/10.3905/jwm.2014.16.4.048

Sum, V. 2014b. Economic policy uncertainty and stock market returns, International Review of Applied Financial Issues and Economics (Forthcoming).

http://dx.doi.org/10.2139/ssrn.2073184

Wright, P. M.; McMahan, G.; McWilliams, A. 1994. Human resources and sustained competitive advantage: a resource-based perspective, International Journal of Human Resource Management 5(2): 301-326. http://dx.doi.org/10.1080/09585199400000020

Vichet SUM (Dr), a native of Cambodia, is currently a tenured Associate Professor in the Department of Business, Management and Accounting, where he teaches management, finance and accounting courses; Sum's AACSB classification is academically qualified (AQ) or scholarly academic (SA). His areas of specialization include Financial Theories, Financial Economics and Econometrics, Financial Management, Managerial and Financial Accounting, Real Estate Finance, Macroeconomics of Imperfect Capital Markets, Monetary Policy Economics, Development Economics, Inferential Statistics, Strategic Human Resource Training \& Development, Industrial Management, and Assessments and Evaluations of the Competitiveness of the Nations. Sum's research studies have appeared in various leading economics and finance journals. In addition, Sum's research articles have been cited in leading academic journals, books, industry reports and both national and international media outlets such as Bloomberg, Washington Post, Chicago Tribune, Businessweek, Australia Financial Review, Les Échos (French Financial Newspapers) and China National News. 